\title{
Kontraksi Ekonomi di Masa Pandemi COVID-19: Entrepreneur Pulihkan Ekonomi Nasional dengan Entrepreneurship
}

\author{
Amaliah Robhiatul Adawiyah \\ Program Studi Kewirausahaan \\ Universitas Bina Nusantara \\ amaliah.adawiyah@binus.ac.id
}

Wuhan, Cina, merupakan sebuah daerah yang menjadi sebuah akar permasalahan terjadinya pandemi yang dimulai pada akhir tahun 2019. Status awal sebelum terjadinya sebuah pandemi dunia adalah epidemik, dimana terus terjadi peningkatan jumlah kematian yang disebabkan oleh sebuah virus Corona yang membuat status berubah menjadi pandemi. Menurut Tedros Adhanom Ghebreyesus yang merupakan Direktur Jenderal Organisasi Kesehatan Dunia atau World Health Organization (WHO), menyebutkan bahwa lebih dari seratus delapan belasribu orang yang terjangkit virus Corona atau yang lebih dikenal saat ini adalah virus COVID-19, tersebar di berbagai negara atau mencapai seratus sepuluh negara. Pada Februari 2020, virus COVID-19 mulai masuk ke Indonesia yang dimulai dari sebuah pesta dansa Klub Paloma \& Amigos di Jakarta. Penyebaran virus COVID-19 mencapai lima ribu seratus tiga puluh enam orang pada April 2020 (Masrul et al., 2020). Pandemi COVID-19 juga berdampak pada ekonomi Nasional Indonesia yang mengalami penurunan hingga -5,32\% di Triwulan II 2020 (Santoso, 2020) yang mengakibatkan terjadinya kontraksi ekonomi.

Ekonomi Nasional Indonesia yang mengalami penurunan pada Triwulan II berhasil memulih dengan mengalami peningkatan secara perlahan pada Triwulan berikutnya sebesar - 3,49\%. Terdapat proses turn point yang membuat Triwulan IV 2020 mengalami perbaikan lebihbaik dari Triwulan III. Hal ini diperkuat karena adanya peningkatan sebesar $2.8 \%$ pada Purchasing Manager's Index (PMI), yang dapat diartikan bahwa PMI berada di level ekspansi. Serta terjadinya peningkatan perkembangan inflasi tingkat konsumen, yang dapat diartikan adanya perbaikan pada permintaan masyarakat (Santoso, 2020). Pada tahun 2021, ekonomi global diperkirakan akan segera pulih dengan pertubuhan positif. Pemerintah Indonesia memberikan upaya pemulihan tersebut dengan menjalankan sebuah Program Pemulihan Ekonomi Nasional, yang diberikan kepada UMKM (Limanseto, 2021). UMKM merupakan sebuah usaha mikro yang dimiliki dan dijalankan oleh seorang entrepreneur yang memenuhi seluruh kriteria usaha mikro, serta menjadi pilar penting untuk memulihkan ekonomi Nasional(Idris, 2021). Tiap individu entrepreneur tentu perlu mempunyai ilmu entrepreneurship yang baik agar dapat memulihkan ekonomi Nasional. 
Kewirausahaan atau entrepreneurship memiliki definisi sebagai suatu proses yang dilakukan oleh entrepreneur atau seseorang yang memiliki ketertarikan dengan 'wirausaha' untuk mengejar adanya sebuah peluang, yang nantinya dapat digunakan sebagai pemenuh kebutuhan hidup dengan adanya sebuah inovasi tanpa memperhatikan sumber daya (Robbin and Coulter, 1997). Proses yang dapat dimulai oleh seorang entrepreneur adalah dengan menyusun business plan. Business plan atau rencana bisnis merupakan sebuah dokumen tertulis yang secara rinci dan detail menjelaskan setiap aspek dari usaha bisnis, yang dapat membantu seorang entrepreneur untuk mengembangkan 'road map' dalam menjalankan strategi serta perencanaan bisnisnya. Proses business plan yang efektif adalah dengan mengidentifikasi ide bisnis, menyaring ide atau gagasan dalam menentukan kelayakan bisnis, melakukan analisis kelayakan dengan melihat apakah ide bisnis tersebut dapat dilanjutkan, serta menuliskan perencanaan produk hingga keuangan (Barringer, 2015). Sehingga dengan menerapkan entrepreneurship, seorang entrepreneur dapat memaksimalkan bisnisnya, terutama pada permasalahan ekonomi di masa pandemi COVID-19 dimana seorang entrepreneurship dapat memulihkan ekonomi Nasional.

\section{References}

Barringer, B.R. (2015). Preparing Effective BusinessPlans: An Entrepreneurial Approach. Global Edition, 2nd, 288. Pearson Education Limited.

Idris, M. (2021, March 26). Apa Itu UMKM: Pengertian, Kriteria, dan Contohnya. Kompas.com.https://money.kompas.com/read/2021/03/26/153202726/apa-ituumkm-pengertian- kriteria-dan-contohnya?page=all

Limanseto, H. (2021, April 28). Dukungan Pemerintah Bagi UMKM Agar Pulih di Masa Pandemi. Ekon.go.id. https://www.ekon.go.id/publikasi/detail/2939/dukunganpemerintah-bagi- umkm-agar-pulih-di-masa-pandemi

Masrul, Abdillah, L. A., Tasnim, Simarmata, J., Daud, Sulaiman, O. K., Prianto, C., Iqbal, M., Purnomo, A., Febrianty, Saputra, D. H., Purba, D. W., Vinolina, N. S., Napitupulu, D., Soetijono, I. K., Ramadhani, Y. R., Jamaludin, Sari, D. C., Muhammad, R. M., ... Faried, A. I. (2020). Pandemik COVID-19: Persoalan dan Refleksi di Indonesia. Yayasan Kita Menulis. https://kitamenulis.id/download/416/ Santoso, Y. I. (2020, December 23). Ekonomi kuartal IV-2020 diyakini bakal membaik, berikut indikatornya. Kontan.co.id. https://nasional.kontan.co.id/news/ekonomikuartal-iv-2020-diyakini-bakal-membaik-berikut-indikatornya 


\section{Biografi}

\section{Amaliah Robhiatul Adawiyah}

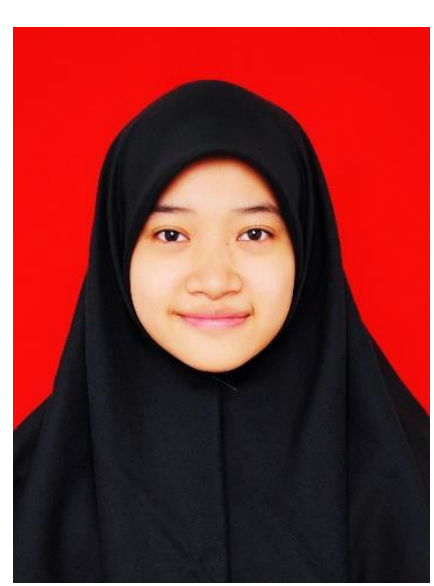

Penulis kelahiran Surabaya ini adalah seorang mahasiswa program studi kewirausahaan di Universitas Bina Nusantara, kampus Malang sejak tahun 2020. Amaliah berkepribadian energik, kreatif, dan antusias. Memiliki ketertarikan dalam entrepreneur, desain grafis, dan analisis penyelesaian masalah. Amaliah sedang berfokus dalam perencanaan ide bisnis 'PUT U Millennial Taste' . Penggemar lagu pop, electronic dance music, alternative/indie dan warna earthy color. Prinsip hidupnya adalah 'whatever you are, be a good one'

Email:amaliah.adawiyah@binus.ac.id

Instagram: @amaliahrobhiatul

Linkedin: https://www.linkedin.com/in/amaliah-robhiatul-adawiyah-9300b2220/ URL: https://about.me/amaliahrobhiatuladawiyah 